MOREIRA, A. S.; CONT ARDI, L. M.; CAMILO, L. J.; ANDRADE, M. G. O.; LIMA, S. F.; VENDRUSCULO, E. P.; SIMON, C. A. Azospirillum brasilense and compound of phytohormones as biostimulants in Jalo Precoce beans. Re vista de Agricultura Neotropical,Cassilândia-MS,v.8,n.2, e5974, abr./jun. 2021. ISSN 2358-6303. DOI: https://doi.org/10.32404/rean.v8i2.5974.

\title{
Azospirillum brasilense and compound of phytohormones as biostimulants in Jalo Precoce beans
}

\section{Allisson Sousa Moreira1, Lucymara Merquides Contardi², Lucas Jandrey Camilo ${ }^{3}$, Maria Gabriela Oliveira Andrade ${ }^{4}$, Sebastião Ferreira Lima ${ }^{1}$, Eduardo Pradi Vendruscolo ${ }^{5}$, Cátia Aparecida Simon 6}

${ }^{1}$ Universidade Federal de Mato Grosso do Sul, Campus de Chapadão do Sul. Chapadão do Sul, Mato Grosso do Sul, Brasil. E-mail: allisson_moreira@hotmail.com, sebastiao.lima@ufms.br

${ }^{2}$ Universidade Estadual Paulista “Júlio de Mesquita Filho”, Campus de Ilha Solteira, Ilha Solteira, São Paulo, Brasil. E-mail: lu_contardi@hotmail.com

${ }^{3}$ Universidade Federal de Mato Grosso do Sul, Campus de Chapadão do Sul, Chapadão do Sul, Mato Grosso do Sul, Brasil. E-mail: luucasjandrey@hotmail.com

${ }^{4}$ Universidade Estadual Paulista “Júlio de Mesquita Filho", Campus de Botucatu, Botucatu, São Paulo, Brasil. E-mail: gabriela13andrade@hotmail.com

${ }^{5}$ Universidade Estadual de Mato Grosso do Sul, Unidade Universitária de Cassilândia, Cassilândia, Mato Grosso do Sul, Brasil. Email: agrovendruscolo@gmail.com

${ }^{6}$ Universidade de São Paulo, Campus de Piracicaba, Piracicaba, São Paulo, Brasil. E-mail: catiasimonsimon@gmail.com

Received: 15/03/2021; Accepted: 24/05/2021.

\begin{abstract}
Beans are one of the most important crops in Brazil but still have a low yield. The use of technologies such as the application of biostimulants can provide greater yield for the crop. Thus, the work aimed to evaluate the effect of using Azospirillum brasilense and phytohormones on Jalo Precoce beans. The experiment was carried out in randomized blocks with nine treatments and four replications. The treatments consisted of a control, Stimulate (compound of phytohormones), and A. brasilense applied isolated or associated to the seeds or in a furrow. The plant height, stem diameter, shoot dry matter, number of pods per plant, number of grains per pod, the weight of grains per pod, and 100-grain weight were favored by A. brasilense and compound of phytohormones. The highest yield of Jalo Precoce beans ( $2218 \mathrm{~kg} \mathrm{ha}^{-1}$ ) was obtained using the A. brasilense + phytohormone compound applied in the sowing furrow. The grain yield of Jalo Precoce beans showed a high positive correlation with the number of pods per plant and medium correlation with stem diameter and shoot dry matter.
\end{abstract}

Keywords: Phaseolus vulgaris, Diazotrophic bacteria, Inoculation, Growth regulator

\section{Azospirillum brasilense e composto de fitohormônios como bioestimulantes em feijão Jalo Precoce}

\section{RESUMO}

O feijão é uma das culturas mais importantes no Brasil, mas ainda apresenta baixa produtividade. O uso de tecnologias como a aplicação de bioestimulantes pode proporcionar maior produtividade para a cultura. Assim, o objetivo do trabalho foi avaliar o efeito do uso de Azospirillum brasilense e fitohormônios em feijão Jalo Precoce. $\mathrm{O}$ experimento foi conduzido em blocos casualizados com nove tratamentos e quatro repetições. Os tratamentos foram constituídos por testemunha; Stimulate (composto de fitohormônios) e A. brasilense aplicados isolados ou as sociados nas sementes ou em sulco de cultivo. A altura de plantas, diâmetro do caule, massa seca da parte aérea, número de vagens por planta, número de grãos por vagem, massa de grãos por vagem e massa de cem grãos foram favorecidos pelo uso de A. brasilense e composto de fitohormônios. A maior produtividade de grãos de feijão Jalo Precoce (2218 kg ha-1) foi obtida com o uso de A. brasilense + composto de fitohormônios aplicados no sulco de cultivo. A produtividade de grãos do feijão Jalo Precoce apresentou alta correlação positiva com número de vagens por planta e média correlação com diâmetro do caule e massa seca da parte aérea.

Palavras-chave: Phaseolus vulgaris, Bactérias diazotróficas, Inoculação, Regulador de crescimento.- 


\section{Introduction}

The common bean (Phaseolus vulgaris L.) is one of the main foods that make up the Brazilian diet, mainly due to its good nutritional value and an important protein source. Brazil is the third-largest producer of beans globally, reaching a production of 3.2 million tons in the 2019/20 harvest (Conab, 2021), behind Myanmar with 5.8 million tons and India with 5.3 million tons (FAO, 2019).

Although it is a crop of great expression and high per capita consumption and well-studied worldwide, it still has some limitations in its production management. The average yield is only $1,104 \mathrm{~kg} \mathrm{ha}^{-1}$, according to Conab (2021), and this is due, among other factors, to the low technological level employed. Thus, the introduction of new technologies can contribute to increasing this yield, in addition to improving producer income.

The bean plants manage to take advantage of atmospheric nitrogen from its fixation by bacteria of the genus Rhizobium that remain in symbiosis with the plant roots, reducing nitrogen fertilization costs; however, this association is not enough to meet all the needs of the plant. In this gap, the use of another bacterium, of the genus Azospirillum, belonging to the plant growth promoter group, has been studied, presenting mechanisms that help produce phytohormones (Hungria et al., 2015).

These bacteria can promote plant growth through physiological changes due to the release of hormones such as auxins and cytokinins that promote increased root growth (Zafar et al., 2012; Hungary et al., 2013). This genus of bacteria has been extensively studied in grass crops (Vendruscolo et al., 2018; Alvarez et al., 2019; Contardi et al., 2020; Silva Junior et al., 2021) with few results for legumes. In soybean crop (Zuffo et al., 2016) and bean cultivars conducted in the winter season (Gitti et al., 2012), no effects on grain yield were observed, although Schossler et al. (2016) have obtained an increase in plant height and number of pods per common bean plant.

Another input with the potential to improve the growth and yield of the bean crop are those that contain phytohormones, which, in addition to playing the plant developmental function, can make it more resistant to environmental stresses, such as lack of water due to the planting seas on or possible dry periods. When applied in the first stages of plant development, they stimulate root growth and provide quick recovery and establishment of the crop (Lana et al., 2009). Almeida et al. (2014) found that the use of growth regulators increased root growth but did not interfere with bean grain yield. Dourado Neto et al. (2014) obtained an increase in grain yield in common bean due to a higher concentration of auxin in the root system, a hormone responsible for cell division and elongation, promoting greater root growth and development. Oliveira et al. (2015) also observed an increase in the yield of cowpea beans.

The Jalo Precoce bean has a short production cycle and great adaptation to different environmental conditions. It can be recommended for different production systems and with high production potential. Furthermore, due to the early cycle, it can favor rotation with other crops, maximizing the use of the rainfall period and increasing the final yield per unit of area. Thus, the objective of this work was to evaluate the effect of using A. brasilense and phytohormones on Jalo Precoce beans.

\section{Material and Methods}

The experiment was conducted in an area of the Federal University of Mato Grosso do Sul, Campus of Chapadão do Sul-MS, Brazil, at $18^{\circ} 46^{\prime} 17.8^{\prime \prime} \mathrm{S}$, at $52^{\circ} 37$ 27.7" $\mathrm{W}$, and altitude of 813 meters. The climate is classified as humid tropical; the annual temperature is between 13 and $28^{\circ} \mathrm{C}$, the average rainfall is $1,850 \mathrm{~mm}$, with a concentration of rain in the summer and drought in the winter (Cunha et al., 2013). The soil of the experimental area was classified as Latossolo Vermelho distrófico (Santos et al., 2018) (Oxysol).

The experimental design used was randomized blocks with nine treatments and four replications, totalling 36 plots. The plots were compound of five rows of five meters in length, spaced $0.45 \mathrm{~m}$ apart, placing 15 seeds per meter of the furrow. The useful area was accounted for in the three central rows of the parcel. One of the useful rows was used to determine the shoot dry matter. Therefore, the plants were destroyed in the evaluation and could not be counted to determine grain yield. The two remaining rows were used.

The treatments consisted of 1) control (C); 2) Stimulate applied to the seed (SS); 3) Azospirillum applied to the seed (AS); 4) Stimulate applied to seed + Azospirillum applied to seed (SS+AS); 5) Stimulate applied in the sowing furrow (SFu);6) Azospirillum applied in the sowing furrow (AFu); 7) Stimulate applied in the sowing furrow + Azospirillum applied in the sowing furrow ( $\mathrm{SFu}+\mathrm{AFu}) ; 8)$ Stimulate applied to seed + Azospirillum applied to sowing furrow (SS+AFu) and 9) Stimulate applied to sowing furrow + Azospirillum applied to seed (SFu+AS).

The products used in the treatments were the Stimulate ${ }^{\circledR}$ biostimulant (cytokinin $0.09 \mathrm{~g} \quad \mathrm{~L}^{-1} \quad+$ gibberellic acid $0.05 \mathrm{~g} \mathrm{~L}^{-1}+4$-indol-3-yl butyric acid $0.05 \mathrm{~g} \mathrm{~L}^{-1}$ ) recommended at a dose of $750 \mathrm{~mL}$ for $100 \mathrm{~kg}$ of seeds and the commercial inoculant Masterfix grasses (strains - AbV5 and AbV6 with 2x108 viable cells $\mathrm{mL}^{-}$ $\left.{ }^{1}\right)$, containing Azospirillum brasilense strains and recommended at a dose of $100 \mathrm{~mL}$ for $50 \mathrm{~kg}$ of seeds. When applied to the seed in the opened furrow at the time 
of sowing, Stimulate was applied at a dose of $1500 \mathrm{~mL}$ $\mathrm{ha}^{-1}$ and Azospirillum at $1000 \mathrm{~mL} \mathrm{ha}^{-1}$, with a spray flow rate of $156 \mathrm{~L} \mathrm{ha}^{-1}$.

The experiment was installed on February 19, 2014, using seeds of the common bean cultivar Jalo Precoce treated with the fungicide Carboxin + Tiram $(60+60 \mathrm{~g}$ a.i. per $100 \mathrm{~kg}$ of seeds). Desiccation management was carried out seven days before sowing to eliminate weeds, using Glyphosate $\left(1.0 \mathrm{~kg}\right.$ a.i. $\left.\mathrm{ha}^{-1}\right)+2.4 \mathrm{D}$ (1.0 kg a.a._ha$\left.{ }^{1}\right)$. The furrow opening and fertilizer distribution were carried out mechanically with a five-row tractor-mounted mechanical seeder.

Seed distribution and top dressing were performed manually. The sowing fertilization was $500 \mathrm{~kg} \mathrm{ha}^{-1}$ of the 4-14-8 NPK formula. The top dressing was done at 20 DAE, applying $80 \mathrm{~kg} \mathrm{ha}^{-1}$ of $\mathrm{N}$ and $40 \mathrm{~kg} \mathrm{ha}^{-1}$ of $\mathrm{K}_{2} \mathrm{O}$, using urea $(45 \% \mathrm{~N})$ as a nitrogen source and $\mathrm{KCl}$ as a potassium source $\left(58 \% \mathrm{~K}_{2} \mathrm{O}\right)$. The experimental area was fallow for two harvests, with no history of use of Azospirillum spp.

The chemical management of weeds in the crop was carried out in the initial phase of cultivation using the herbicide Fomesafen + Fluazifop-p-butyl + paraffinic mineral oil at a dose of $250 \mathrm{~g}+125 \mathrm{~g}+171.2 \mathrm{~g}$ of ai ha ${ }^{1}$. No other applications were made.

The characteristics evaluated were: (a) Plant height measurement from the surface of the soil to the tip of the plants; (b) stem diameter - measured with a digital caliper just above the ground surface; (c) number of leaves - total number of fully expanded leaves in the plant; (d) shoot dry matter - the plants were cut at ground level, placed in duly identified paper bags and placed in a forced ventilation oven at $65^{\circ} \mathrm{C}$ until reaching constant weight. For all evaluations, ten plants from one of the rows of the useful area were used when the crop was in full bloom, which occurred 28 days after emergence.

The other characteristics evaluated were: (e) number of pods per plant - counting all the pods of 10 plants separated from the useful area of the plot at the time of harvest; (f) number of grains per pod - obtained from 10 pods separated from the total number of pods of 10 plants; (g) grain weight per pod - the total grains obtained from ten pods were weighed to obtain the grain weight per pod; (h) 100-grain weight - obtained by weighing 100 grains separated from the useful area of the plot and (i) grain yield - the plants of the two rows of the useful area of the plot were pulled out manually, dried in the environment and then threshed. Afterobtaining the grain weight per plot, this value was transformed to $\mathrm{kg} \mathrm{ha}^{-1}$.

The moisture for the weight of grains per pod, the 100 -grain weight and yield were corrected to $13 \%$, as it is a standard value for storage. This moisture was obtained according to the equation:

$$
\mathrm{PCC}=(\mathrm{PC}(100-\mathrm{Uob})) /((100-\mathrm{Ud}))
$$
Where:
PCC = corrected field weight;
$\mathrm{PC}=$ field weight;
$\mathrm{Uob}=$ observed moisture;
$\mathrm{Ud}=$ desired moisture.

For statistical analysis, the data were subjected to analysis of variance, using the Scott-Knott test at 5\% probability for comparis on of means, using the Sisvar program (Ferreira, 2011). Correlation network and canonical variables analyzes were also performed with the support of the Rbio program (Bhering, 2017).

\section{Results and Discussion}

The use of $A$. brasilense bacteria and the phytohormones compound applied in seeds, in furrows, or combined affected the characteristics of plant height, stem diameter, number of leaves, and shoot dry weight (Figure 1).

With the use of Stimulate in beans, applied both on seeds and in the sowing furrow, Bertolin et al. (2010) and Almeida et al. (2014) found no effect for plant height regardless of application time. For the use of Azospirillum bacteria, Gitti et al. (2012) obtained an $8.0 \%$ increase in dry matter in dry beans, but without statistical significance.

Some studies already indicate a positive effect of the use of diazotrophic bacteria for grass crops such as corn, beans, and rice, among others; however, studies with non-grass plants are still incipient and need to be expanded to validate the use of this technology. It is observed in this work that the treatment with the two products applied in furrows resulted in a higher value in the four variables (treatment $7-\mathrm{SFu}+\mathrm{AFu}$ ) (Figure 1). This beneficial effect of $A$. brasilense and phytohormones is probably due to the ability of these products to promote greater plant growth (Lana et al., 2009; Hungria et al., 2015).

For plant height, stem diameter, and shoot dry matter, the $\mathrm{SFu}+\mathrm{AFu}$ treatment resulted in gains of $9.3 \% .11 .6 \%$ and $24.3 \%$, respectively, compared to the control, even though this treatment did not differ from some others, but it was always superior to the control. There was no benefit from the use of biostimulants for the number of leaves, but the application of Azospirillum in the cultivation furrow $(\mathrm{AFu})$ harmed the formation of leaves (Figure 1).

The treatments also influenced the number of pods per plant, the number of grains per pod, the weight of grains per pod, and the 100-grain weight (Figure 2).

All treatments, except $\mathrm{SS}+\mathrm{AFu}$ and $\mathrm{SFu}+\mathrm{AS}$, were favorable to the increase of pods per plant (Figure 2), being, on average, $16.6 \%$ above the value obtained in control. 

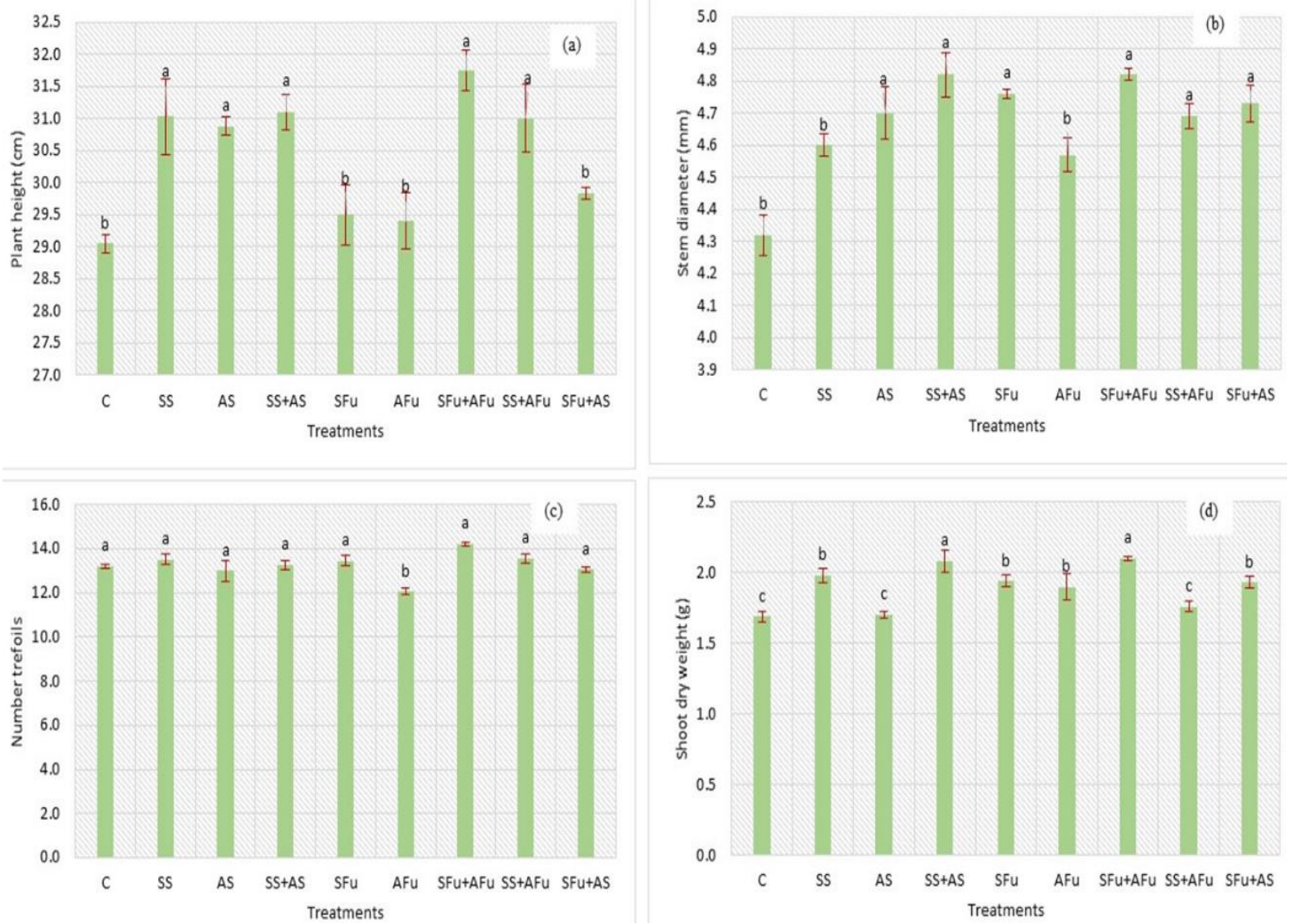

Figure 1. Plant height (a), stem diameter (b), number of leaves (c), and shoot dry matter (d) as a function of the use of A. brasilense and Stimulate in seeds of Jalo Precoce bean.

C- Control; SS- Stimulate applied to the seed; AS- Azospirillum applied to the seed; SFu- Stimulate applied in the furrow; AFuAzospirillum applied in the furrow. The same letters on the columns do not differ statistically between $5 \%$ probability by the ScottKnott test.
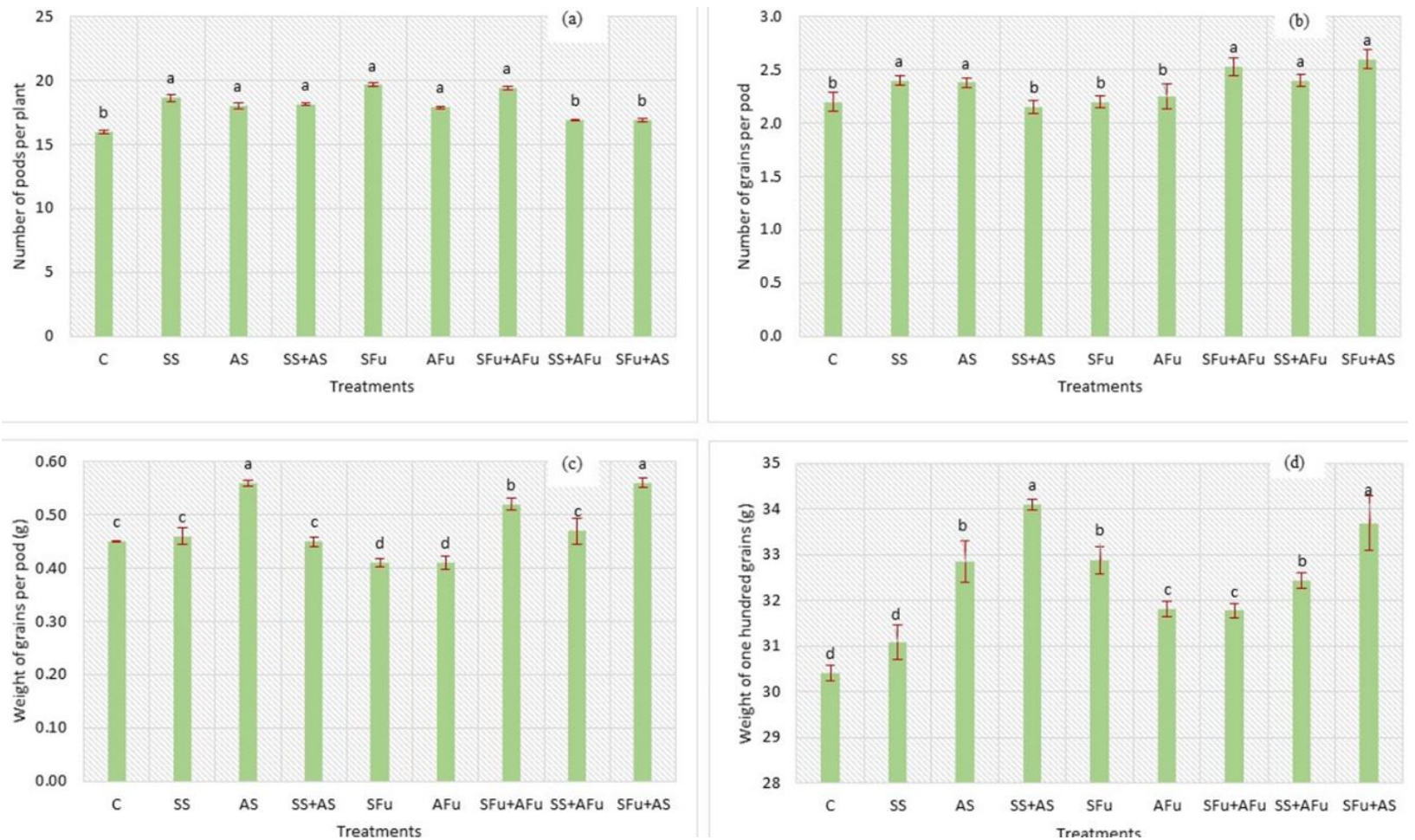

Figure 2. Number of pods per plant (a), number of grains per pod (b), weight of grains per pod (c), and 100-grain weight (d) as a function of the use of A. brasilense and Stimulate in seeds of Jalo Precocious bean.

C-Control; SS- Stimulate applied to the seed; AS- Azospirillum applied to the seed; SFu- Stimulate applied in the furrow; AFuAzospirillum applied in the furrow. The same letters on the columns do not differ statistically bet ween 5\% probability by the ScottKnott test. 
Bertolin et al. (2010) also found an increase in the number of pods perbean plant when they used a seed and leaf bioregulator. Still, Bernardes et al. (2010) found no significant effect for the number of pods per plant using biostimulant in common bean. Using A. brasilense, Schossler et al. (2016) obtained a higher number of pods per plant in common bean.

The highest grain yield (Figure 3) was observed for the treatment with A. brasilense and phytohormones applied in the furrow (SFu+AFu), representing a gain of $29.2 \%$ concerning the control. As reported by Ávila et al. (2008), the way of applying Stimulate can influence the yield and other variables of the common bean. It is also possible to observe in the present work that the form of application of Azospirillum is an essential factor.

Gitti et al. (2012) achieved a gain of $103 \mathrm{~kg} \mathrm{ha}^{-1}$ of the bean when they used inoculation with A. brasilense. Despite not being statistically different from the control, they considered the economic is sue as positive. Hungria et al. (2013) obtained a $19.6 \%$ increase in bean grain yield when they used seed inoculation with Rhizobium tropici as sociated with the application of $A$. brasilense in the furrow. Due to the lack of responses for grain yield in legumes related to the use of Azospirillum (Gitti et al., 2012; Zuffo et al., 2016) and the possibilities of an association with phytohormones or other biostimulants, a range of studies open up, able to provide more information to producers in decision-making to improve the bean crop.

Seeking to understand better how each variable interacted with each other, a correlation analysis was performed, and to facilitate the interpretation of correlations between variables, a two-dimensional correlation network was set up. In the correlation network generated from the Pearson matrix, positive correlations were expressed in green lines, and negative correlations were expressed in red lines. The magnitude of the correlation is proportional to the thickness of the lines (Figure 4).

Most correlations were positive, except for WGP with NPP and NT with WHG, which correlated negatively, both with low magnitude. CO correlated positively, from medium to high magnitude, with WHG, NPP, SDW, GY, $\mathrm{PH}$. This result indicates that plants with larger diameters generally have greater plant heights, greater shoot dry weight, greater 100-grain weight, greater number of pods per plant, and greater grain yield. WGP, NGP, and NT were also positively correlated with SD but in smaller magnitudes.

GY had a highly positive correlation with NPP and medium proportions with SD and SDW, indicating that as the number of pods per plant, shoot dry weight, and stem diameter increase, yield increases. WGP also had a high-magnitude positive correlation with NGP, indicating that the higher number of pods on the plants is related to the higher the number of grains present in them.

The treatments, except SS+AS, SFu, and AFu, were favorable to increasing the number of grains per pod (Figure 2), providing gains of $11.9 \%$ concerning the control. Bernardes et al. (2010) did not find positive and significant results in the number of grains per pod using growth regulators in common bean. Likewise, using $A$. brasilense, Gitti et al. (2012) and Schossler et al. (2016) found no positive effect on the number of grains per pod in common bean.

The treatments AS and SFu+AS resulted in the highest seed weight per pod (Figure 2), resulting in gains of $24.4 \%$ above the control value. For the 100-grain weight, the treatments SS+AS and SFu+AS (Figure 2) provided gains of $11.5 \%$ above the control. Gitti et al. (2012) and Schossler et al. (2016) found no increase in grain weight using A. brasilense in common bean plants.

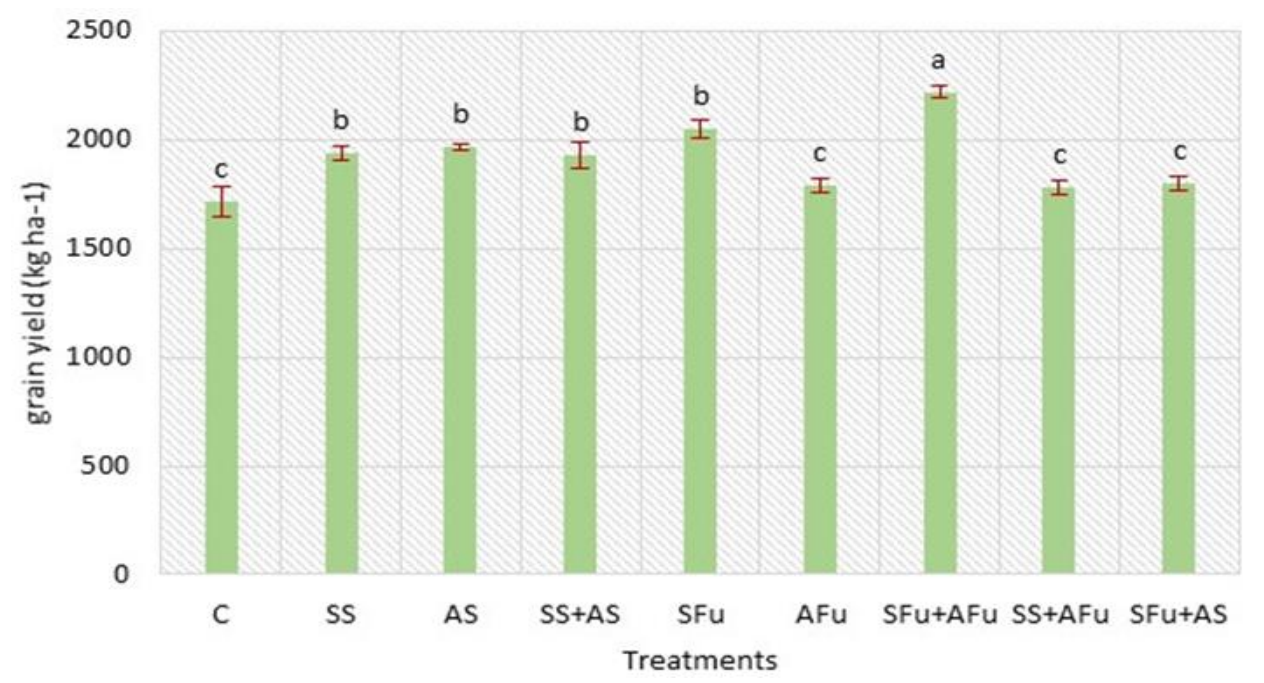

Figure 3. Grain yield as a function of the use of A. brasilense and Stimulate in seeds of the Jalo Precoce bean C-Control; SS- Stimulate applied to the seed; AS- Azospirillum applied to the seed; SFu- Stimulate applied in the furrow; AFuAzospirillum applied in the furrow. The same letters on the columns do not differ statistically between 5\% probability by the Scott Knott test. 


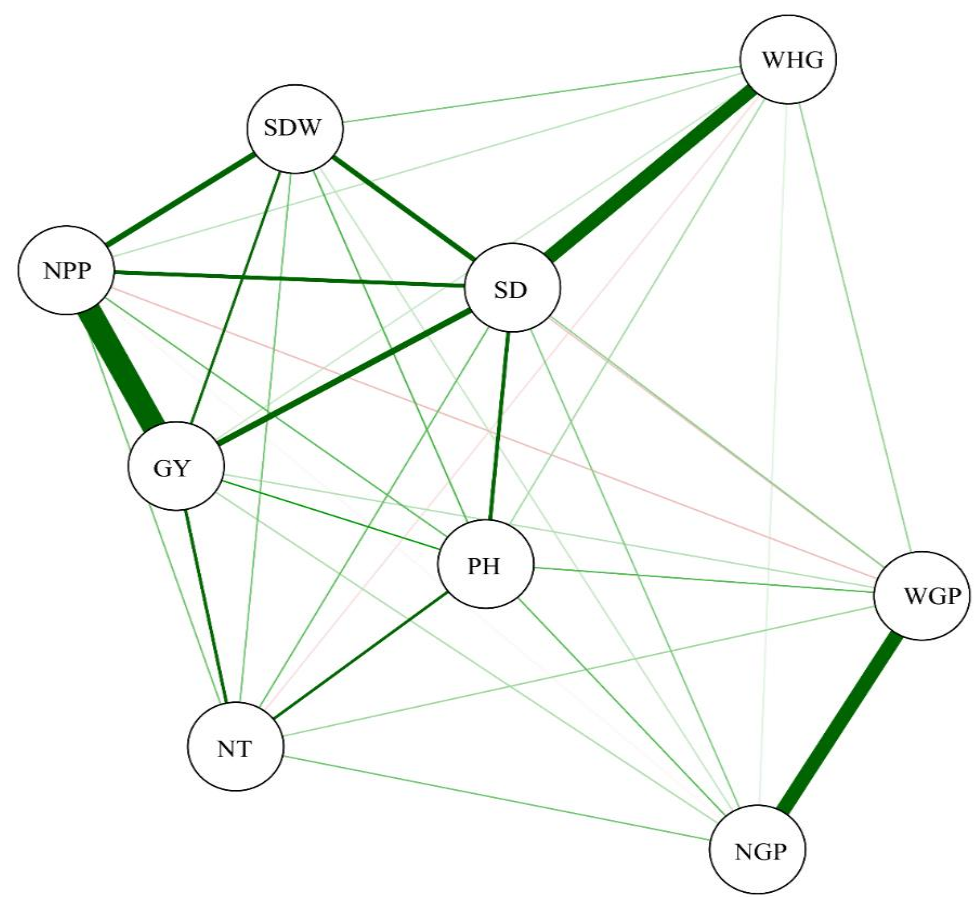

Figure 4. Correlation network between the variables: PH (plant height), SD (stem diameter), NT (number of leaves), SDW (shoot dry weight), NPP (number of pods per plant), NGP (number of grains per pod), WGP (Weight of grains per pod), WHG (100-grain weight) and GY (Grain yield). Positive correlations were highlighted in green, and negative correlations were highlighted in red. The thickness of the lines is proportional to the magnitude of the correlation.

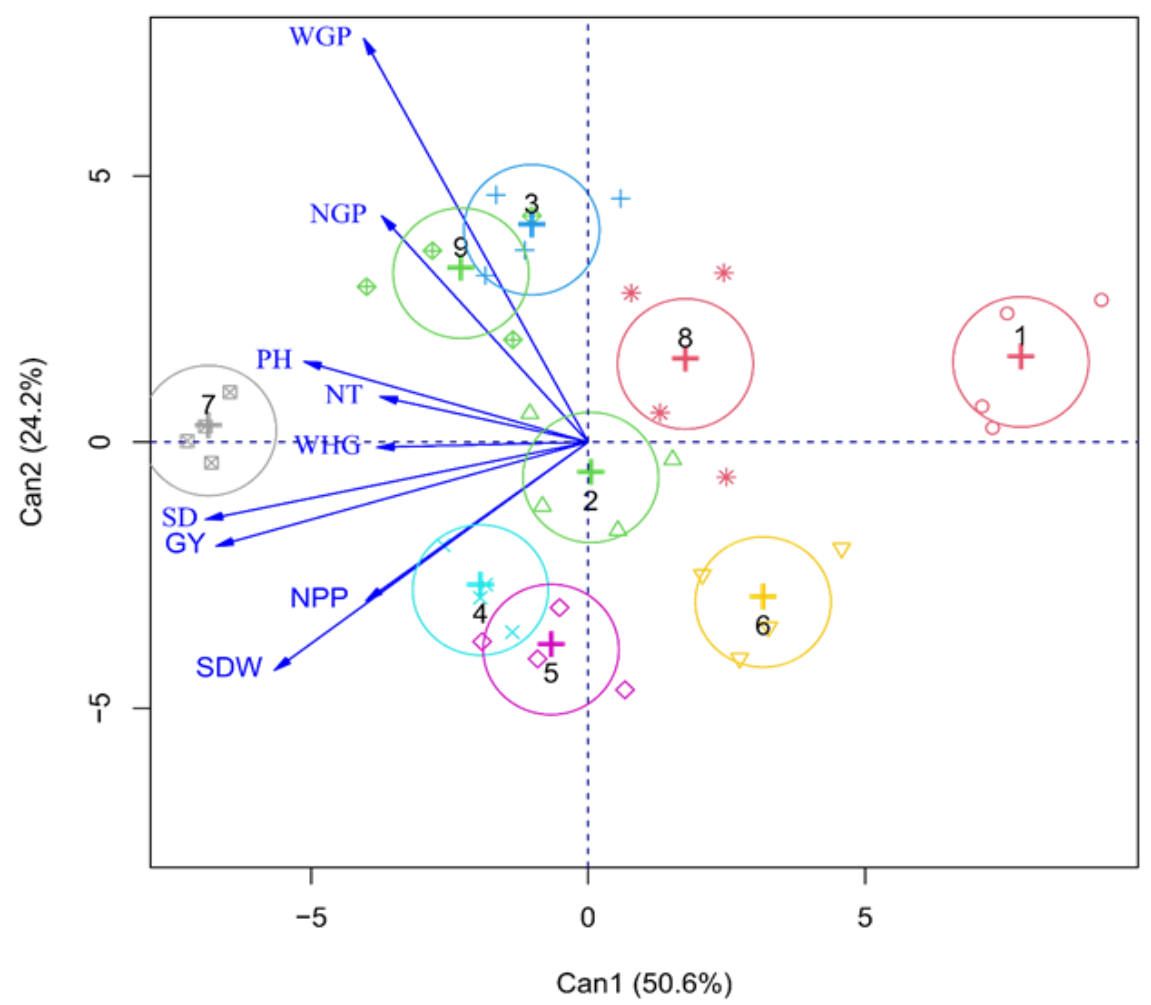

Figure 5. Analysis of canonical variables between treatments and variables: PH (plant height), SD (stem diameter), NT (number of leaves), SDW (shoot dry weight), NPP (number of pods per plant), NGP (number of grains per pod), WGP (Weight of grains per pod), WHG (100-grain weight) and GY (Grain yield). 
The positive effects observed in the production components of Jalo Precoce beans are probably due to the is olated or joint action of biostimulants on the physiology of the plants. A. brasilense is characterized as a growth promoter and is capable of causing physiological changes in plants due to the release of hormones such as auxins and cytokinin, which induce root growth, leading the plant to absorb more water and nutrients (Zafar et al., 2012; Hungria et al., 2015).

Canonical variable analysis was used to verify the contribution of each variable to the difference between treatments. In this work, the accumulation of the first two canonical variables was $74.8 \%$, allowing an accurate interpretation in a two-dimensional graph (Figure 5). It was observed that treatments 1 (control), 6(Azospirillum applied in the sowing furrow), and 8 (Stimulate applied in the seed + Azospirillum applied in the sowing furrow) did not stand out specifically regarding any analyzed variable.

Treatment 2 (Stimulate applied to the seed) was closer to the origin of the vectors, with the smallest divergence between treatments. Treatments 4 and 5 (Stimulate applied to the seed + Azospirillum applied to the seed and Stimulate applied to the sowing furrow, respectively) showed similarity to each other, and the variables that contributed to this were the NPP and SDW vectors. Treatments 3 (Azospirillum applied to the seed) and 9 (Stimulate applied to the sowing furrow + Azospirillum applied to the seed) were also similar, and the variables NGP and WGP contributed to this.

The variables PH, NT, WHG, SD, and GY had higher values for treatment 7 (Stimulate applied in the sowing furrow + Azospirillum applied in the sowing furrow), meaning that this treatment was effective in increasing the respective growth and bean grain yield.

\section{Conclusions}

The use of Azospirillum brasilense and the phytohormones compound is favorable to the growth characteristics, production components, and yield of the Jalo Precoce bean.

The use of A. brasilense + phytohormones compound applied in the furrow is indicated to achieve a higher grain yield of Jalo Precoce beans.

The Jalo Precoce bean grain yield had the greatest contribution from the number of pods per plant, stem diameter and shoot dry weight, verified by the positive correlation between these variables.

\section{Authors' Contribution}

Allisson Sousa Moreira: preparation, conception, design, and data acquisition; Lucymara Merquides Contardi: data analysis, and interpretation; Lucas Jandrey
Camilo: design, data analysis, and interpretation; Maria Gabriela Oliveira Andrade and Sebastião Ferreira Lima: preparation, conception, design, data analysis, and interpretation; Eduardo Pradi Vendruscolo, and Cátia Aparecida Simon: data acquisition, data analysis, and interpretation.

\section{Bibliographic References}

Almeida, A.Q., Soratto, R.P., Broetto, F., Cataneo, A.C. 2014. Nodulação, aspectos bioquímicos, crescimento e produtividade do feijoeiro em função da aplicação de bioestimulante. Semina: Ciências Agrárias, 35(1), 77-88. DOI: http://dx.doi.org/10.5433/1679-0359.2014v35n1p77

Alvarez, R.C.F., Benetão, J., Barzotto, G.R., Andrade, M.G.O., Lima, S.F. 2019. Application methods of Azospirillum brasilense in first and second-crop corn. Revista Brasileira de Engenharia Agrícola e Ambiental, 23(11), 840-846. DOI: https://doi.org/10.1590/1807-1929/agriambi.v23n11p840-846

Ávila, M.R., Barizão, D.A.O., Gomes, E.P., Fedri. G., Albrecht. L.P. 2008. Bioregulator application, agronomic efficiency, and quality of soybean seeds. Scientia Agricola, 65(6), 604-612. DOIS: https://doi.org/10.1590/S0103-90162008000600006

Bernardes, T.G., Silveira, P.M., Mesquita, M.A.M. 2010. Produtividade do feijoeiro irrigado devido a reguladores de crescimento e culturas antecessoras de cobertura. Bragantia, 69(2), 371-375. DOI: https://doi.org/10.1590/S000687052010000200015

Bertolin, D.C., Sá, M.E., Arf, O., Furlani Junior, E., Colombo, A.S., Carvalho, F.L.B.M. 2010. Aumento da produtividade de soja com a aplicação de bioestimulantes. Bragantia, 69(2), 339347. DOI: http://dx.doi.org/10.1590/S000687052010000200011

Bhering, L.L. 2017. Rbio: A Tool For Biometric And Statistical Analysis Using The R Platform. Crop Breeding and Applied Biotechnology, 17(2), 187-190. DOI: https://doi.org/10.1590/1984-70332017v17n2s29

CONAB. COMPANHIA NACIONAL DE ABASTECIMENTO. 2021. Acompanhamento safra brasileira de Grãos. v. 8 - Safra 2015/16, n. 6 - Sexto levantamento, Brasília. https://www.conab.gov.br/info-agro/safras (acessado 14 de abril de 2020)

Contardi, L.M., Alvarez, R.C.F., Lima, S.F., Paiva Neto, V.B., Brasil, M.S., Ramires, R.V. 2020. Nitrogen management and application of Azospirillum brasilense in corn. Research, Society and Development, 9(8), e553985791. DOI: http://dx.doi.org/10.33448/rsd-v9i8.5791

Cunha, c.c., Magalhães, F.F., Castro, M.A. 2013. Métodos para estimativa da evapotranspiração de referência para Chapadão do Sul - MS. Engenharia na Agricultura, 21(2), 159-172. DOI: https://doi.org/10.13083/reveng.v21i2.346

Dourado Neto, D., Dario, G.J.A., Barbieri, A.P.P., Martin, T.N. 2014. Ação de bioestimulante no desempenho agronômico de milho e feijão. Bioscience Journal, 30(Supl.1), 371 - 379. http://www.seer.ufu.br/index.php/biosciencejournal/article/vie w/18110/14549. (acessado em 10 de Maio de 2020) 
FAO. FOOD AND AGRICULTURE ORGANIZATION. 2019. http://faostat.fao.org. (accessed March 10, 2021)

Ferreira, D.F. 2011. Sisvar: A computer statistical analysis system. Ciência e Agrotecnologia, 35(6), 1039-1042. DOI: https://doi.org/10.1590/S1413-70542011000600001

Gitti, D.C., ARF, O., Kaneko, F.H., Rodrigues, R.A.F., Buzetti, S., Portugal, J.R., Corsini, D.C.D.C. 2012. Inoculação de Azospirillum brasilense em cultivares de feijões cultivados no inverno. Revista Agrarian, 5(15), 36-46. DOI: https://doi.org/10.30612/agrarian.v5i15.1297

Hungria M., Nogueira, M.A., Araujo, R.S. 2015. Soybean seed co-inoculation with Bradyrhizobium spp. and Azospirillum brasilense: a new biotechnological tool to improve yield and sustainability. American Journal of Plant Science, 6(10), 811817. DOI: http://dx.doi.org/10.4236/ajps.2015.66087

Hungria, M., Nogueira, M.A., Araujo, R.S. 2013. Coinoculation of soybeans and common beans with rhizobia and azospirilla: strategies to improve sustainability. Biology and Fertility of Soils, 49(7), 791-801, 2013. DOI: https://doi.org/10.1007/s00374-012-0771-5

Lana, A.M.Q., Lana, R.M.Q., Gozuen, G.F., Bonotto, I., Trevisan, L.R. 2009. Aplicação de reguladores de crescimento na cultura do feijoeiro. Bioscience Journal, 25(1), 13-20. DOI: http://www.seer.ufu.br/index.php/biosciencejournal/article/vie w/6699. (acessado em 10 maio de 2020)

Oliveira, F.A., Medeiros, J.F., Alves, R.C., Lima, L.A., Santos, S.T., Regis. L.R. 2015. Produção de feijão caupi em função da salinidade e regulador de crescimento. Revista Brasileira de Engenharia Agricola e Ambiental, 19(11), 1049 - 1056. DOI: https://doi.org/10.1590/1807-1929/agriambi.v19n11p10491056
Santos, H.G., Jacomine, P.K.T., Anjos, L.H.C., Oliveira, V.A., Lumbreras, J.F., Coelho, M.R., Almeida, J.A., Araujo Filho, J.C., Oliveira, J.B., Cunha, T.J.F. 2018. Sistema Brasileiro de Classificação de Solos. Brasília: Embrapa. https://www.embrapa.br/solos/sibcs.(accessed March 11, 2020)

Schossler, J.H., Meert, L., Rizzardi, D.A., Michalovicz, L. 2016. Componentes de rendimento e produtividade do feijoeiro comum submetido à inoculação e coinoculação com estirpes de Rhizobium tropici e Azospirillum brasilense. Revista Scientia $\begin{array}{lll}\text { Agraria, } & 17(1), & 10-15 .\end{array}$ http://dx.doi.org/10.5380/rsa.v17i1.47409

Silva Junior, J.A.M., Freitas, J.M., Rezende, C.F.A. 2021. Corn productivity associated with inoculation with Azospirillum brasilense and different doses of nitrogen fertilization. Research, Society and Development, 10(2), e42810212711. DOI: https://doi.org/10.33448/rsd-v10i2.12711

Vendruscolo, E.P., Siqueira, A.P.S., Furtado, J.P.M., Campos, L.F.C., Seleguini, A. 2018. Development and quality of sweet maize inoculated with diazotrophic bacteria and treated thiamine. Revista de Agricultura Neotropical, 5(4), 45-51. DOI: https://doi.org/10.32404/rean.v5i4.2766

Zafar, M., Abbasi, M.K., Khan, M.A. Khaliq, A., Sultan, T., Aslam, M. 2012. Effect of Plant Growth Promoting Rhizobacteria on Growth, Nodulation and Nutrient Accumulation of Lentil Under Controlled Conditions. Pedosphere, 22(6), 848-859. DOI: https://doi.org/10.1016/S1002-0160(12)60071-X.

Zuffo, A.M., Rezende, P.M., Bruzi, A.T., Ribeiro, A.B.M., Zambiazzi, E.V., Soares., I.O., Vilela, N.J.D., Bianchi, M.C. 2016. Soybean cultivars agronomic performance and yield according to doses of Azospirillum brasiliense applied to leaves. Australian Journal of Crop Science, 10(4), 579-583. DOI: https://doi.org./10.21475/ajcs.2016.10.04.p7554x 